\title{
TGF- $\beta 1$ Regulates the Expression of Multiple Max-Interacting Transcription Factors in Balb/MK Cells: Implications for Understanding the Mechanism of Action of TGF- $\beta 1$
}

\author{
DANIEL J. SATTERWHITE, RAYMOND L. WHITE, MARY E. AAKRE, AND HAROLD L. MOSES \\ Department of Cell Biology and Cancer Center, Vanderbilt University School of Medicine, Nashville, \\ Tennessee 37232-6838, U.S.A. [M.E.A., H.L.M.], and Departments of Pediatrics [D.J.S.] and Oncological \\ Sciences [R.L.W.], University of Utah School of Medicine, Salt Lake City, Utah 84132, U.S.A.
}

\begin{abstract}
Appropriate transforming growth factor- $\beta 1$ (TGF- $\beta 1)$ signaling is required to preserve homeostasis of diverse tissues during development. At the cellular level, one function of TGF- $\beta 1$ that is critical for preserving homeostasis is the ability to arrest cell growth. TGF- $\beta 1$ arrests growth by blocking the function of the $\mathrm{c}-m y c$ proto-oncogene. c-myc function is determined by the level of c-myc expression relative to other Max-interacting transcription factors, and TGF- $\beta 1$ has been shown to inhibit c-myc expression by inhibiting c-myc transcription. However, whether TGF- $\beta 1$ might also increase the expression of a Max-interacting factor that blocks myc function by competing with $m y c$ for Max binding is not known. Therefore, we determined the effect of TGF- $\beta 1$ on the expression of Max-interacting transcription factors in Balb/MK cells. We found unexpectedly that Balb/MK cells express both $\mathrm{N}-m y c$ and c-myc. The pattern of N-myc expression during the cell cycle differs from that of c-myc, indicating that mRNA accumulation is controlled by mechanisms specific to each gene. TGF- $\beta 1$ rapidly inhibits N-myc mRNA expression; thus N-myc is a novel target of TGF- $\beta 1$ in Balb/MK cells. More importantly, we found that TGF- $\beta 1$ induces the expression of the putative tumor suppressor genes Mad4 and
\end{abstract}

\section{ABSTRACT}

Mxi1 in both the Balb/MK and Mv1Lu cell lines. Mad4 and Mxi1 are novel targets of TGF- $\beta 1$, known to inhibit cell growth by antagonizing the interaction of Myc with Max. Thus, our results suggest that the induction of Mad4 and Mxil may function in tandem with the inhibition of $\mathrm{N}-m y c$ and c-myc to mediate the growth inhibitory function of TGF- $\beta 1$. (Pediatr Res 50: 67-75, 2001)

\section{Abbreviations}

TGF- $\boldsymbol{\beta} 1$, transforming growth factor- $\beta 1$

Balb/MK, mouse keratinocyte cell line

$\mathbf{p R b}$, retinoblastoma protein

cdk, cyclin-dependent kinase

DRB, 5,6 dichloro-1-beta-D-ribofuranosylbenzimidazole

Mv1Lu, mink lung epithelial cell line

HDAC, histone deacetylase

EGF, epidermal growth factor

FBS, fetal bovine serum

FACS, fluorescence-activated cell sorter

TCE, TGF- $\boldsymbol{\beta} 1$ control element
TGF- $\beta 1$ is the prototypical member of a large family of growth factors that preserve tissue homeostasis during development $(1,2)$. One function of TGF- $\beta 1$ that is critical for normal development is the ability to regulate cell proliferation. To illustrate, animals grow larger during development

Received June 2, 2000; accepted January 5, 2001.

Correspondence and reprint requests: Daniel J. Satterwhite, M.D., Department of Pediatrics, Division of Neonatology, University of Utah School of Medicine, 50 North Medical Drive, Salt Lake City, UT 84132, U.S.A.; e-mail: Dan.Satterwhite@hsc.utah.edu

Supported by the Pediatric Scientist Development Program (National Institute of Child Health and Development) grant HD-00850 (D.J.S.), Vanderbilt Skin Diseases Research Center (National Institute of Health/National Institute of Arthritis and Musculoskeletal and Skin Diseases) grant 1 P30 AR41943-01A1 (D.J.S.), the Primary Children's Medical Center Foundation (D.J.S.), the Huntsman Cancer Institute (R.L.W and D.J.S.), grants CA42572 and CA48799 from the National Cancer Institute (H.L.M.), and the Frances Williams Preston Laboratory funded by the T.J. Martell Foundation (H.L.M.). principally by accumulating more cells through the process of cell division (3). Virtually every cell relies on signals from the extracellular environment to decide whether it is appropriate to continue to divide, or whether it should revert to the nondividing, so-called quiescent state. Deregulated signaling through the TGF- $\beta 1$ pathway results in a diverse array of developmental abnormalities depending on the tissue type and the component of the TGF- $\beta 1$ signaling pathway that is affected [reviewed in Raff (2)]. Accordingly, the study of TGF- $\beta 1$ function has revealed many of the components of signaling pathways that are critical for the appropriate regulation of cell division during development.

The direct effect of TGF- $\beta 1$ on the growth of many cell types in vitro and in vivo is to inhibit cell proliferation $(4,5)$. TGF- $\beta 1$ arrests cell growth by inhibiting key proto-oncogenes 
and activating key tumor suppressor genes that affect cell cycle progression. The first evidence of this came with the observation that the response of cells to the TGF- $\beta 1$ growth arrest signal is dependent on cell cycle position. In general, cells decide whether to divide based on extracellular growth signals during the $\mathrm{G}_{1}$ phase of the cell cycle, before the onset of DNA synthesis (S-phase) [reviewed in Pardee (6)]. Accordingly, TGF- $\beta 1$ has been shown in many cell types to reversibly arrest cell cycle progression at a point in late $\mathrm{G}_{1}$ when added before the $G_{1} / S$ transition (7-10). A key event in the $G_{1}$ cell cycle arrest induced by TGF- $\beta 1$ is the ability of TGF- $\beta 1$ to convert the retinoblastoma tumor suppressor protein $(\mathrm{pRb})$ to the underphosphorylated, growth-suppressive form that binds E2F (8, $11,12)$. TGF- $\beta 1$ inhibits the phosphorylation of $\mathrm{pRb}$ by inhibiting the activation of Cdks during $\mathrm{G}_{1}$. TGF- $\beta 1$ can inhibit both cyclin and Cdk expression [reviewed in Satterwhite et al. (10) and Ko et al. (13)], and also can induce specific inhibitors of Cdk activation $(14,15)$.

The c-myc proto-oncogene functions at least in part to mediate the activation of Cdks by extracellular growthpromoting signals $[(7,12,16-21)$, also reviewed in Obaya et al. (22)]. Cells do not progress normally through $\mathrm{G}_{1}$ when c-myc expression is perturbed, indicating that $\mathrm{c}-m y c$ has an essential function in $\mathrm{G}_{1}(23-25)$. Inhibition of c-myc transcription by TGF- $\beta 1$ treatment was first shown to be important in the TGF- $\beta 1$-induced arrest of mouse keratinocytes (26), and has been reported in numerous other TGF- $\beta 1$-responsive cell lines (27-32). Subsequently it has been shown that inhibition of c-myc by TGF- $\beta 1$ is required for inactivation of Cdk 4 by induction of the $\mathrm{p} 15^{\mathrm{Ink} 4 \mathrm{~b}} \mathrm{Cdk}$ inhibitor (33). Conversely, activation of a conditional Myc-estrogen receptor chimera in Balb/MK cells resulted in resistance to TGF- $\beta 1$-induced late $\mathrm{G}_{1}$ arrest, indicating that c-Myc overactivity is sufficient to override the inhibitory effects of TGF- $\beta 1$ on the cell cycle machinery (34). Forced expression of c-myc in Mv1Lu cells prevented the inactivation of $\mathrm{Cdk} 4$ in response to TGF- $\beta 1$, principally by preventing induction of $\mathrm{p} 15^{\mathrm{Ink} 4 \mathrm{~b}}$ (33). Thus, blocking myc function results in a block of the phosphorylation of $\mathrm{pRb}$ by Cdks in late $\mathrm{G}_{1}$. Blocking myc function is both necessary and sufficient to mediate the TGF- $\beta 1$-induced antiproliferative signal.

c-Myc functions as a transcription factor by binding with the protein Max to form a heterodimer. It is known that c-Myc competes with other proteins for Max binding, and the relative abundance of each of these proteins is the primary force determining Max dimer composition. For example, signals that induce cell differentiation have been shown to induce expression of the Mad family of proteins including Mxil $(35,36)$. When present in abundance, Mad proteins bind Max. These Mad/Max heterodimers oppose the function of Myc/Max dimers on artificial Myc-responsive reporter constructs (35, 37). Mad/Max heterodimers repress transcription by recruiting $\mathrm{HDAC}$ to the DNA via the mSin3A corepressor [reviewed in Pazin and Kadonaga (38)]. This model describing the regulation of myc function continues to evolve as new members in this regulatory scheme are identified. Further, it is becoming clear that the various partners of Max confer very complex effects on wild-type promoters depending on sequence varia- tions in the myc binding site or in the regions flanking the myc binding site (39-41). Although the inhibition of c-myc expression by TGF- $\beta 1$ has been studied extensively in the past (12, 26,42 ), the possibility that TGF- $\beta 1$ might block myc function by inducing the expression of a Max-interacting transcription factor that opposes myc function has not been reported.

We performed studies to determine whether TGF- $\beta 1$ affects the expression of a group of Max-interacting transcription factors in Balb/MK. Balb/MK is a spontaneously immortalized cell line derived from primary mouse keratinocytes. Balb/MK cells are nontransformed and sensitive to TGF- $\beta 1$-induced growth arrest; therefore, they provide a useful model system in which to study gene expression in the control of nontumorigenic cell proliferation. We did not expect to find expression of $\mathrm{N}-m y c$ or L-myc in Balb/MK cells, because the expression of multiple myc proto-oncogenes has been described only in transformed cells. However, because the c-myc, N-myc, and $\mathrm{L}-m y c$ proteins are thought to be able to function interchangeably in promoting cell growth [reviewed in Marcu et al. (43)], we predicted that if $\mathrm{N}-m y c$ or L-myc were expressed, TGF- $\beta 1$ would inhibit the expression. Conversely, several of the Maxinteracting transcription factors that oppose myc function are known or putative tumor suppressor genes. Consistent with the idea that TGF- $\beta 1$ functions in part by activating tumor suppressor genes, we predicted that TGF- $\beta 1$ might increase the expression of one of the Max-interacting transcription factors previously known to oppose myc function.

\section{METHODS}

Cell culture and synchronization. Balb/MK cells (a gift from Stuart Aaronson) were grown in $175 \mathrm{~cm}^{2}$ flasks (Falcon 3045, Franklin Lakes, NJ, U.S.A.) or $150 \mathrm{~cm}^{2}$ flasks (Corning, Cambridge, MA, U.S.A.) in an incubator in 5- 7\% $\mathrm{CO}_{2}$ at $37^{\circ} \mathrm{C}$. Growth medium consisted of minimal essential medium with $5 \mathrm{mg} / \mathrm{L}$ calcium (MEM Lo $\mathrm{Ca}^{2+}$, JRH Biosciences, Lenexa, KS, U.S.A.), 8\% dialyzed FBS (JRH Biosciences, Lenexa, KS, U.S.A. and GIBCO BRL, Rockville, MD, U.S.A.), and $4 \mathrm{ng} / \mathrm{mL}$ EGF (Becton Dickenson, Franklin Lakes, NJ, U.S.A.). Medium was replaced daily or every other day.

To obtain cell cycle synchronization, cells were cultured in synchronization medium (MEM Lo $\mathrm{Ca}^{2+}, 0.1 \% \mathrm{FBS}$, with no added EGF) for $72 \mathrm{~h}$. Balb/MK cells became arrested in the $\mathrm{G}_{0}$ phase of the cell cycle at subconfluence by $72 \mathrm{~h} . \mathrm{G}_{0}$-arrested cells were restimulated to grow by replacing the synchronization medium with growth medium at time zero. Because the addition of growth medium functioned to stimulate the $\mathrm{G}_{0}$ arrested cells to reenter the cell cycle, the addition of growth medium to $\mathrm{G}_{0}$-arrested cells is referred to as mitogenic stimulation, and the growth medium as mitogen.

Mv1Lu cells (CCL-64, American Type Culture Collection, Rockville, MD, U.S.A.) were grown in $150-\mathrm{cm}^{2}$ flasks (Corning, Cambridge, MA, U.S.A.) in an incubator in $5 \% \mathrm{CO}_{2}$ at $37^{\circ} \mathrm{C}$. Growth medium consisted of Dulbecco's modified Eagle medium (DMEM, GIBCO BRL, Rockville, MD, U.S.A.), 5\% dialyzed FBS (GIBCO BRL, Rockville, MD, U.S.A.), and 4 ng/mL EGF (Becton Dickenson, Franklin Lakes, NJ, U.S.A.). 
Rapidly growing, pooled primary mouse keratinocytes were isolated and cultured in vitro using a standard protocol (44). All studies involving animal subjects were approved as required by the respective Institutional Review Boards.

Porcine TGF- $\beta 1$ (R\&D Systems, Minneapolis, MN, U.S.A.) was added to a final concentration of $10 \mathrm{ng} / \mathrm{mL}$ at the times indicated.

DNA synthesis was assessed in synchronized cultures by measuring $\left[{ }^{3} \mathrm{H}\right]$-thymidine incorporation. Forty microcuries of $\left[{ }^{3} \mathrm{H}\right]$-thymidine (Dupont/NEN, Boston, MA, U.S.A.) was added per $175-\mathrm{cm}^{2}$ flask, and labeling was allowed to proceed for $2 \mathrm{~h}$. Cells were then washed, fixed in $10 \%$ trichloroacetic acid, and lysed in $0.2 \mathrm{~N}$ sodium hydroxide. $\left[{ }^{3} \mathrm{H}\right]$-thymidine incorporation (cpm) was measured in triplicate at time zero in quiescent cells and after $24 \mathrm{~h}$ of EGF-induced growth, both with and without the addition of TGF- $\beta 1$. Cell cyclesynchronized Balb/MK had approximately 100 -fold higher $\left[{ }^{3} \mathrm{H}\right]$-thymidine incorporation in S-phase than in $\mathrm{G}_{0} / \mathrm{G}_{1}$, and the addition of TGF- $\beta 1$ in mid- $\mathrm{G}_{1}$ consistently inhibited S-phase entry by $60-70 \%$ in independent experiments $(10)$.

Cell cycle distribution was determined using a standard protocol for FACS analysis (45).

RNA isolation, Northern analysis, and quantitation. Cells were harvested at the times indicated in each figure, and either total RNA (Figs. 1 and $2 D$ ) or polyadenylated RNA (Figs. $2 A$, $3 A$, and 4 ) was isolated using a standard protocol $(46,47)$. Whole cell lysates were pooled from one to two flasks for each time point when total RNA was isolated, and two to three flasks when polyadenylated RNA was isolated. RNA was resolved by electrophoresis on an agarose gel and transferred to Hybond, Zetaprobe, or Magnacharge membranes. Complete transfer was confirmed by ethidium bromide staining.

Total RNA from rapidly growing, pooled primary mouse keratinocytes was a gift from Dr. Anna Maria Garcia.

$\left[{ }^{32} \mathrm{P}\right] \mathrm{dATP}-$ and $\left[{ }^{32} \mathrm{P}\right] \mathrm{dCTP}-$ (Amersham, Piscataway, NJ, U.S.A. or Dupont/NEN, Boston, MA, U.S.A.) labeled probes were made using a random primer DNA labeling kit (Boehringer Mannheim, Indianapolis, IN, U.S.A.). The following cDNA templates were used for random primed labeling: the 0.7-kb BamHI/PstI fragment from plasmid SP65 $1 \mathrm{~B} 15$ containing the rat cyclophilin cDNA, kindly provided by Patria E. Danielson; the 850-bp HincII/PstI fragment from the p277 construct containing the murine $\mathrm{N}-m y c$ gene, kindly provided by Ron DePinho; the 1-kb XbaI/ScaI insert from pSV-c-myc containing murine c-myc, kindly provided by Robert Weinberg; the 1-kb EcoRI fragment from the human Mad1 cDNA (35); the 2.5-kb murine Mxil cDNA, kindly provided by Bunsiti Simizu; the 1.2-kb EcoRI fragment from the Mad3 cDNA, the 1.2-kb EcoRI fragment from the Mad4 cDNA, the $1.5-\mathrm{kb}$ HindIII-XbaI fragment from pcDNA3/Hdac containing the histone deacetylase-1 cDNA, and the 1.7-kb HindIII fragment from pSPmSin3A containing the mSin3A cDNA, kindly provided by Don Ayer; the 550-bp EcoRI fragment from pVZ1 p21Max containing the human Max cDNA (48); the 800-bp $\mathrm{SacI}$ fragment from mL2Gemb containing the second exon of the murine L-myc gene, kindly provided by Kari Alitalo; and the 550- bp HindIII fragment from SVpSP65-B-myc containing human B-myc (49). The N-myc and c-myc DNA fragments used for probes were subcloned into pBluescript and sequenced to confirm their identities. Hybridizations were performed at $42^{\circ} \mathrm{C}$ using $1 \times 10^{6} \mathrm{cpm} / \mathrm{mL}$ of labeled DNA in hybridization buffer containing $50 \%$ formamide.

Images and quantification of signal intensity were obtained using a phosphorimager (Molecular Dynamics). Statistical comparisons were made using a two-tailed $t$ test.

Inhibition of $m R N A$ synthesis and $m R N A$ half-life determination. The selective mRNA synthesis inhibitor DRB was used to rapidly block N-myc mRNA production, and the decay of N-myc message was calculated by Northern analysis of $\mathrm{N}-m y c$ abundance. A final concentration of $100 \mu \mathrm{M}$ DRB was used; this was the lowest dose that maximally inhibited (85\%) $\left[{ }^{3} \mathrm{H}\right]$-uridine incorporation measured for a $1-\mathrm{h}$ period after addition of DRB to Balb/MK cells (data not shown). This dose of DRB did not affect the rate of DNA synthesis in Balb/MK cells as measured by $\left[{ }^{3} \mathrm{H}\right]$-thymidine incorporation during the first $2 \mathrm{~h}$ of DRB treatment (data not shown). Vehicle alone (DMSO at a final concentration of $0.2 \%$ ) did not affect either $\left[{ }^{3} \mathrm{H}\right]$-uridine or $\left[{ }^{3} \mathrm{H}\right]$-thymidine incorporation (not shown). Nmyc signal intensity was normalized to cyclophilin expression to control for loading differences among samples. This approach may yield a slight overestimation of the true length of the half-life, because cyclophilin levels also slowly decrease after addition of DRB. However, the half-life of cyclophilin was found to be $>12 \mathrm{~h}$ long, and the cyclophilin mRNA expression seen by Northern analysis did not vary significantly from the intensity of the ribosomal bands, which apparently were not affected by DRB based on ethidium staining of the gel before blotting (not shown). As cyclophilin expression is not affected by TGF- $\beta 1$, this approach has the advantage of allowing very accurate comparison between TGF- $\beta 1$-treated and -untreated samples at any given time point after the addition of DRB in blots made with either total RNA or RNA enriched for polyadenylated message.

\section{RESULTS}

$N$-myc is rapidly inhibited by TGF- $\beta 1$. Because inhibition of c-myc mRNA expression has been shown to play an important role in mediating the effects of TGF- $\beta 1$ on cell cycle progression, we performed Northern analysis to determine whether TGF- $\beta 1$ might affect N-myc or L-myc mRNA expression. L-myc mRNA was not detected in Balb/MK cells (not shown). However, by Northern analysis we detected a single 2.9-kb band corresponding to the expected size of the N-myc mRNA using a ${ }^{32} \mathrm{P}$-labeled fragment from the 3 ' untranslated region of the murine $\mathrm{N}-m y c$ cDNA, a region of $\mathrm{N}-m y c$ that has no homology to c-myc. The N-myc band was distinct from the $2.5-\mathrm{kb}$ band detected using a probe from exon 2 of the murine c-myc gene, indicating that the probes did not cross-hybridize.

Because TGF- $\beta 1$ arrests cell cycle progression in the $\mathrm{G}_{1}$ phase, we examined mRNA expression in Balb/MK cells that were stimulated to progress through the early stages of the cell cycle in a synchronized manner. Signal intensity for each sample was normalized to cyclophilin mRNA expression. We found that TGF- $\beta 1$ inhibited N-myc mRNA expression within $1 \mathrm{~h}$ after treatment during $\mathrm{G}_{1}$ (Fig. $1, A$ and $B$ ). The inhibition 


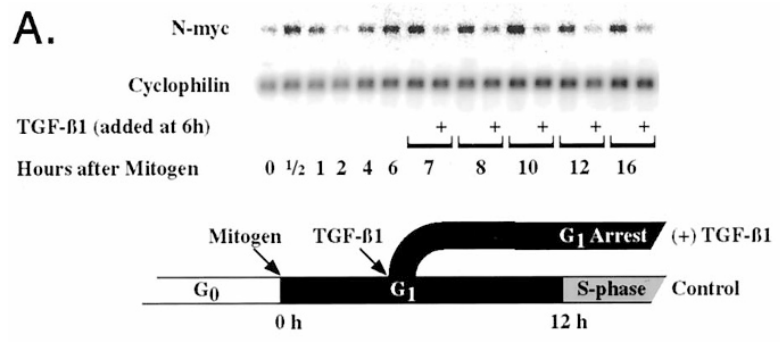

B.

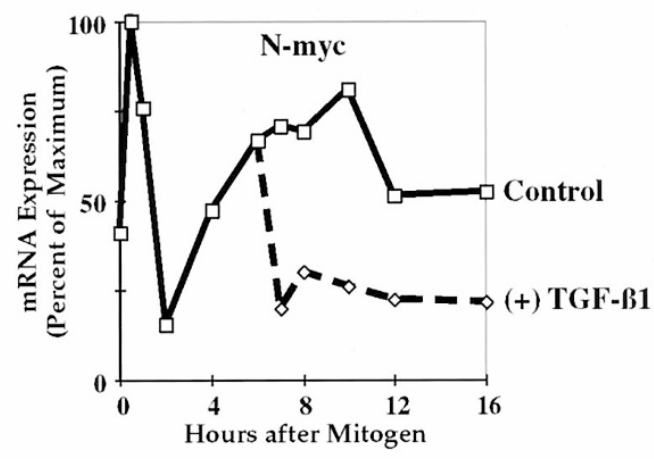

C.

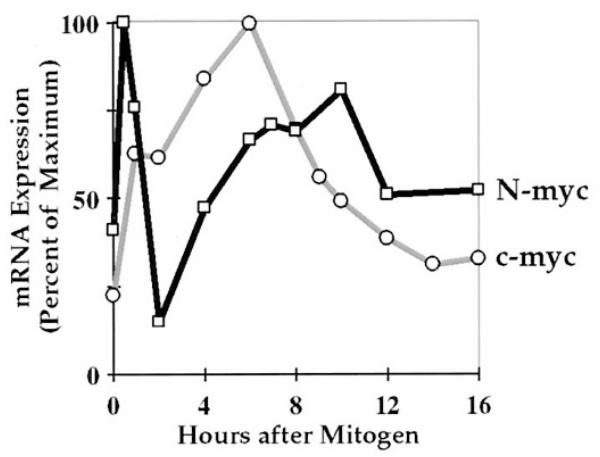

D.

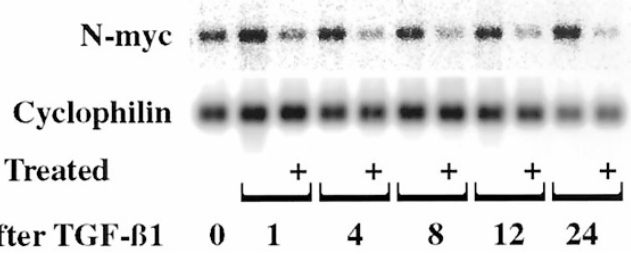

Figure 1. TGF- $\beta 1$ rapidly inhibits N-myc mRNA expression. $A$, response of $\mathrm{N}-m y c$ expression to TGF- $\beta 1$ during the $\mathrm{G}_{1}$ phase of the cell cycle determined by stimulating quiescent $\left(\mathrm{G}_{0}\right)$ Balb/MK cells to reenter the cell cycle by addition of mitogen (growth medium) at $0 \mathrm{~h} .(+)$ indicates TGF- $\beta 1$ added to cells $6 \mathrm{~h}$ after mitogen. Control cells began S-phase approximately $12 \mathrm{~h}$ after mitogen, whereas TGF- $\beta 1$-treated cells arrested in $\mathrm{G}_{1}$. RNA was isolated for Northern blot analysis from cells harvested at the times indicated. Results shown from this single experiment are representative of multiple assays. Shown below is a diagram of experimental design indicating the predominant cell cycle phase at each time point. $B$, signal intensity in Fig. 2A was normalized to cyclophilin expression and represented graphically. Dashed line, $\mathrm{N}-m y c$ mRNA expression in cells treated with TGF- $\beta 16 \mathrm{~h}$ after mitogen. $C$, pattern of N-myc mRNA expression differs from that of c-myc during $\mathrm{G}_{1}$. Black line, $\mathrm{N}-m y c$ expression in control cells; gray line, c-myc expression in control cells (c-myc Northern not shown). $D$, cell cycle synchronization is not required for $\mathrm{N}-m y c$ inhibition by TGF- $\beta 1$. N-myc mRNA expression was rapidly inhibited by TGF- $\beta 1$ in randomly cycling Balb/MK cells. $(+)$ indicates TGF- $\beta 1$ added to asynchronous, rapidly proliferating cells at $0 \mathrm{~h}$. RNA was isolated for Northern blot analysis from cells harvested at the times indicated. Cyclophilin expression was used as a control. The inhibition of N-myc is long-lasting, persisting for $\geq 24 \mathrm{~h}$. Results shown from this single experiment are representative of multiple assays. of N-myc occurred well in advance of the onset of DNA synthesis, which began approximately $12 \mathrm{~h}$ after mitogen, and the inhibition persisted for $\geq 10 \mathrm{~h}$. Thus, the kinetics of the inhibition suggest that inhibition of N-myc is important in mediating the $\mathrm{G}_{1}$ cell cycle arrest induced by TGF- $\beta 1$.

Interestingly, we found that the pattern of expression of $\mathrm{N}-m y c$ differed from that of $\mathrm{c}-m y c$ during the $\mathrm{G}_{1}$ phase of the cell cycle (Fig. 1C). Expression of both N-myc and c-myc was low in nondividing, quiescent Balb/MK. c-myc was rapidly induced by mitogenic stimulation and continued to accumulate during early $\mathrm{G}_{1}$, reaching maximum levels at $6 \mathrm{~h}$. In contrast, $\mathrm{N}-m y c$ had a very rapid spike of expression early in $\mathrm{G}_{1}$. By $4 \mathrm{~h}$, $\mathrm{N}-m y c$ mRNA again began to accumulate, and $\mathrm{N}-m y c$ expression increased through the middle and most of the second half of $\mathrm{G}_{1}$, when c-myc levels were decreasing. The inhibition of c-myc expression by TGF- $\beta 1$ in Balb/MK has been published previously (26).

Likewise, the inhibition of $\mathrm{N}-m y c$ expression was rapid and sustained in asynchronous, randomly cycling Balb/MK cells, persisting for $\geq 24 \mathrm{~h}$ after TGF- $\beta 1$ treatment (Fig. $1 D$ ). The inhibition of N-myc in randomly cycling cells indicates that the inhibition of N-myc is not dependent on cell cycle synchronization in $\mathrm{G}_{1}$. Randomly cycling cells were used for subsequent analyses.

$N$-myc message stability is unaffected by TGF- $\beta 1$. The rapid inhibition of $\mathrm{N}-m y c$ expression by TGF- $\beta 1$ suggests that the $\mathrm{N}$-myc mRNA half-life is $<1 \mathrm{~h}$ in TGF- $\beta 1$-treated $\mathrm{Balb} / \mathrm{MK}$ cells, and therefore a potential target of regulation. To determine the N-myc mRNA half-life, and whether message stability might be affected by TGF- $\beta 1$, message abundance was measured by Northern analysis of RNA from randomly cycling Balb/MK cells after treatment with DRB, a specific inhibitor of RNA-polymerase II-dependent mRNA synthesis (50). In independent experiments, the N-myc half-life was found to be 21.3 $\pm 3.2 \mathrm{~min}$ (mean $\pm \mathrm{SD}, n=3$ ). There was no effect of TGF- $\beta 1$ on the N-myc mRNA stability in any experiment, suggesting that TGF- $\beta 1$ inhibits N-myc mRNA synthesis (Fig. 2).

Mxi1 and Mad4 are induced by TGF-ß31. Because some members of the Max-interacting transcription factor family inhibit cell proliferation by antagonizing Myc activity, we performed northern analysis of mRNA expression in randomly cycling Balb/MK cells to determine whether TGF- $\beta 1$ might induce expression of a Myc antagonist (Fig. 3A). Cell cycle distribution was determined for each sample by FACS analysis (Fig. 3B, 0-20 h) or thymidine incorporation (Fig. 3B, $24 \mathrm{~h}$ ). Balb/MK cells began to accumulate in the $\mathrm{G}_{1}$ phase of the cell cycle between 4 and $8 \mathrm{~h}$ after TGF- $\beta 1$ treatment. A modest induction of Mxil and Mad4 expression was evident at $4 \mathrm{~h}$, before cell cycle arrest. A marked induction of Mxil and Mad4 expression was seen by $8 \mathrm{~h}$, the point when $\mathrm{G}_{1}$ arrest was first detected, and expression continued to increase for $24 \mathrm{~h}$ (Fig. 3, $A$ and $C$ ). The inhibition of N-myc and c-myc by TGF- $\beta 1$ is shown for comparison.

Mad3 signal was not consistently detected; however, a slight $M a d 3$ signal was induced by TGF- $\beta 1$ in one experiment (not shown). The low reproducibility of Mad3 signal detection did not allow us to conclude whether expression of Mad3 is regulated by TGF- $\beta 1$. The mRNA expression levels of Max, 
$M a d 1$, B-myc, $H D A C$, and $m \operatorname{Sin} 3 A$ were not affected by TGF- $\beta 1$ (not shown).

To determine whether the induction of Mxil and Mad4 by TGF- $\beta 1$ is restricted to the Balb/MK cell line, we examined expression in Mv1Lu cells. Mv1 Lu is a polyclonal, nontransformed cell line that is commonly used as a model system for studying mechanisms of TGF- $\beta 1$ growth arrest. Neither N-myc nor L-myc expression was detected in $\mathrm{Mv} 1 \mathrm{Lu}$ cells (not shown), and c-myc mRNA expression was inhibited by TGF- $\beta 1$ as previously reported (Fig. 4A) (32). Mxil and Mad4 expression was significantly elevated in Mv1Lu cells treated with TGF- $\beta 1$ for $24 \mathrm{~h}$ (Fig. 4). We conclude that the induction of Mxil and Mad4 mRNA expression by TGF- $\beta 1$ is not restricted to a single cell type. The induction of Mxil and Mad4 by TGF- $\beta 1$ is associated with cell cycle arrest in both Balb/MK and Mv1Lu cells. The mRNA expression of Max, Madl, B-myc, $H D A C$, and $m \operatorname{Sin} 3 A$ was not affected by TGF- $\beta 1$ in $\mathrm{Mv} 1 \mathrm{Lu}$ cells, and expression of Mad3 was not detected (not shown).

\section{DISCUSSION}

Balb/MK express $N$-myc and $c$-myc. The finding that Balb/MK cells express both $\mathrm{N}-m y c$ and c-myc was quite unexpected, because previously the expression of multiple myc proto-oncogenes in epithelial cell lines has been described only

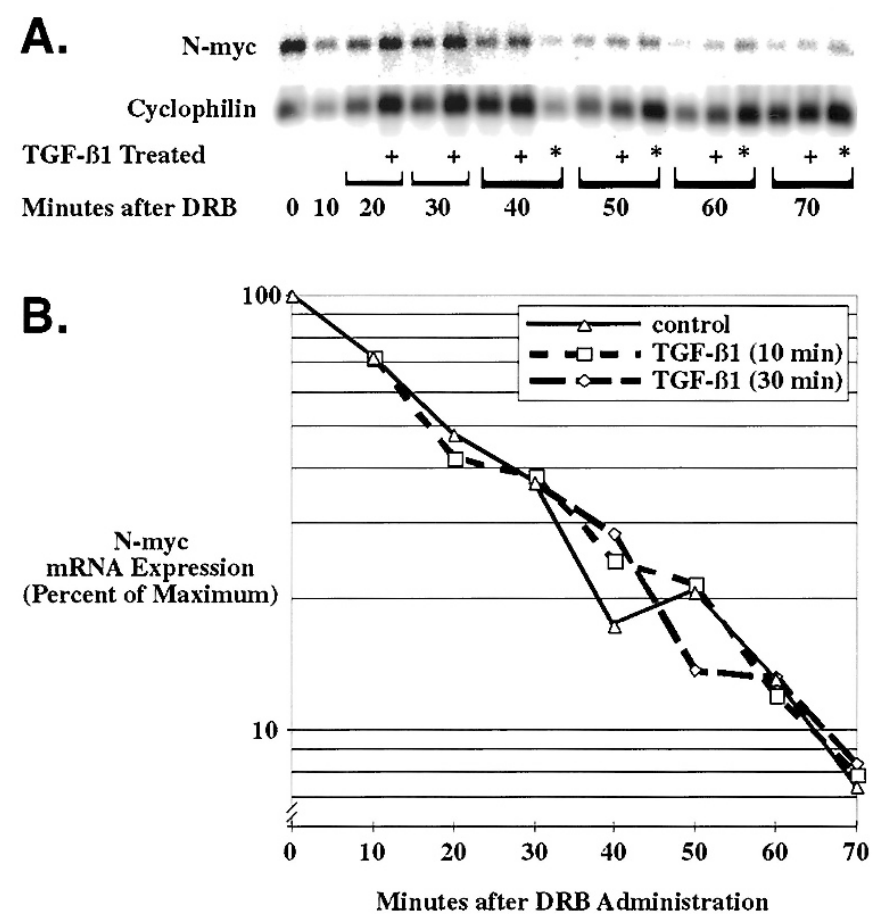

Figure 2. N-myc mRNA stability is not affected by TGF- $\beta 1$. $A$, mRNA synthesis inhibitor, DRB, was added to randomly cycling Balb/MK cells at $0 \mathrm{~h}$. TGF- $\beta 1$ added to cells at $10(+)$ or $30(*)$ min after DRB. RNA was isolated for Northern blot analysis from cells harvested at the times indicated. $B, \mathrm{~N}-m y c$ signal intensity normalized to cyclophilin expression and represented graphically (semi-logarithmically). N-myc mRNA levels decreased immediately after the cessation of mRNA synthesis because of DRB treatment. The N-myc mRNA half-life in this experiment was $20 \mathrm{~min}$, and message stability did not differ for the TGF- $\beta 1$-treated cells. Results shown from this single experiment are representative of multiple assays.
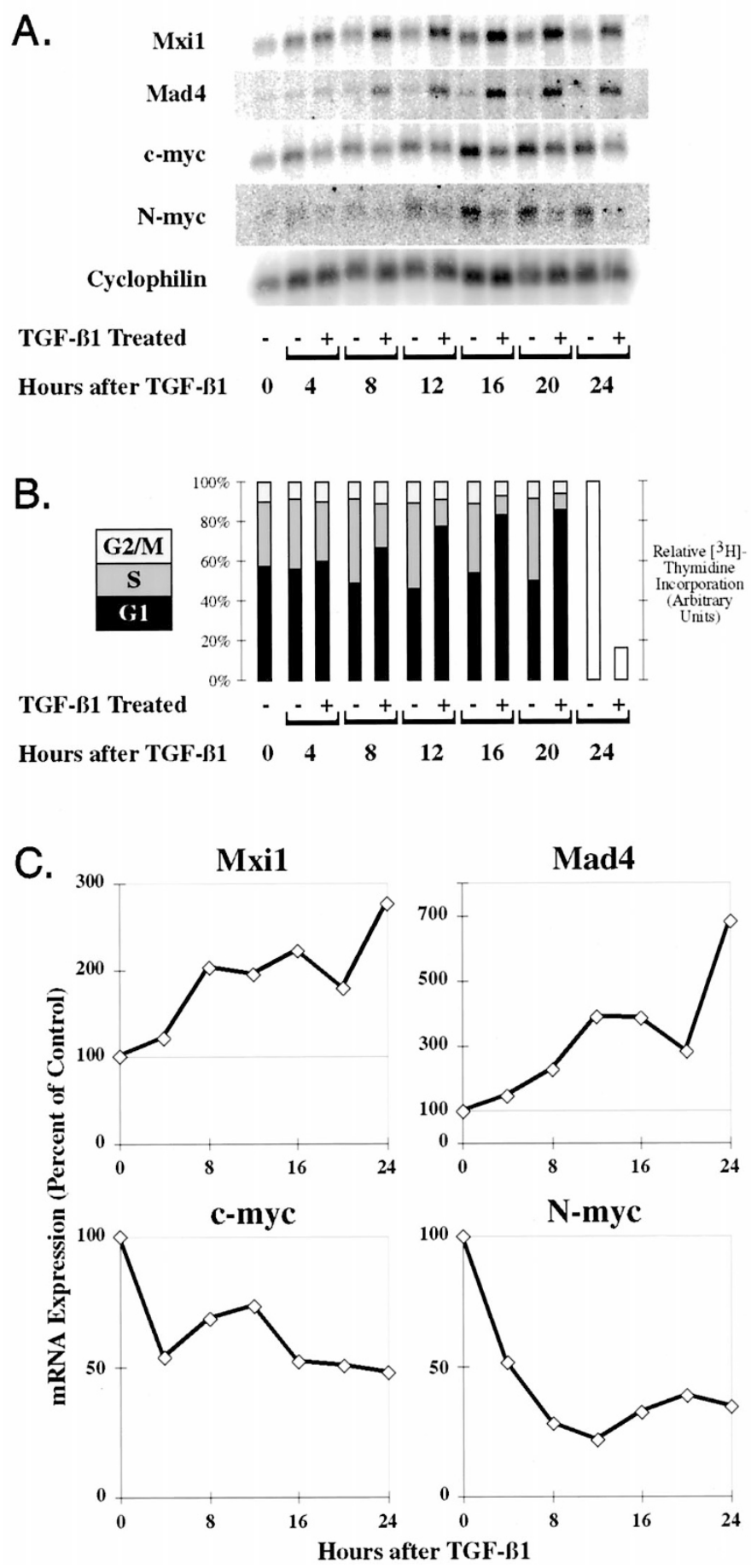

Figure 3. TGF- $\beta 1$ rapidly induces expression of the myc antagonists Mxil and Mad4 in Balb/MK cells. $A,(+)$ indicates TGF- $\beta 1$ added to asynchronous, rapidly proliferating Balb/MK cells at $0 \mathrm{~h}$. RNA was isolated for Northern blot analysis from samples harvested at the times indicated. $B$, analysis of cell cycle distribution by FACS (at times $0-20 \mathrm{~h}$ ) or $\left[{ }^{3} \mathrm{H}\right]$-thymidine incorporation (at $24 \mathrm{~h}$ ) indicated that TGF- $\beta 1$ induced $\mathrm{G}_{1}$ arrest and inhibited thymidine incorporation. $C$, signal intensity normalized to cyclophilin expression and represented graphically (percent of control is equivalent to expression in normalized TGF- $\beta 1$-treated sample relative to expression in corresponding normalized untreated sample). TGF- $\beta 1$ treatment rapidly induced the mRNA expression of Mxil and Mad4 relative to control. The rapid inhibition of $\mathrm{N}-m y c$ and c-myc mRNA expression is shown for comparison. The expression of Max, Mad1, Mad3, B-myc, HDAC, and $m \operatorname{Sin} 3 A$ was not affected by TGF- $\beta 1$ (not shown). Results shown from this single experiment are representative of multiple assays. 

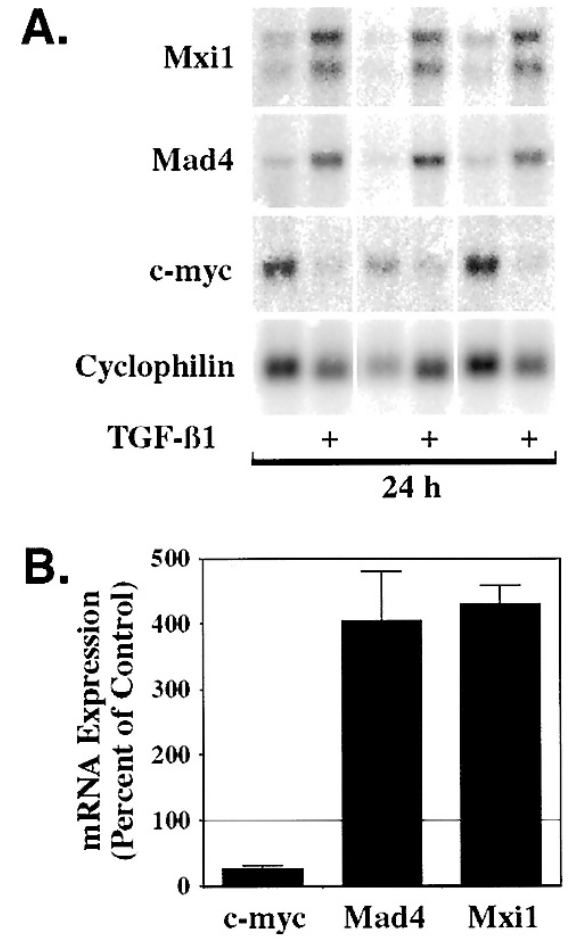

Figure 4. Mxil and Mad4 mRNA expression is also induced by TGF- $\beta 1$ in randomly cycling Mv1Lu cells. $A,(+)$ indicates TGF- $\beta 1$ added to asynchronous, rapidly proliferating cells at $0 \mathrm{~h}$. RNA was isolated for Northern blot analysis from cells harvested at $24 \mathrm{~h}$. Paired samples were run on the same Northern blot ( $n=3$ independent experiments). $B$, signal intensity normalized to cyclophilin expression, and change in expression after TGF- $\beta 1$ represented graphically. Mxil and Mad4 were induced to $430 \pm 28 \%$ (mean \pm SD) and 405 $\pm 76 \%$ of control, respectively $(p<0.05)$. c-myc was inhibited to $25 \pm 3 \%$ of control $(p<0.05)$.

in transformed cells. Thus, we have identified the first nontransformed cell line that expresses both proto-oncogenes. Because growth of cells in culture can substantially alter the patterns of gene expression from that which is observed in vivo, we wondered whether $\mathrm{N}-m y c$ expression in Balb/MK cells might be a characteristic reflective of the cell of origin. Although our experiments did not address this specifically, presumptive evidence supports the conclusion that the Balb/MK cell line was derived from a skin cell that normally expresses N-myc. Within the skin of newborn mice, N-myc is expressed in cells comprising the outer root sheath of the hair bulb $(51,52)$. We know that Balb/MK cells were derived from normal skin, have stringent growth factor requirements, are anchorage dependent, and do not form tumors in nude mice. As further support, we have examined $\mathrm{N}-m y c$ expression in rapidly growing primary mouse keratinocytes isolated from newborn mice and grown in the same manner as those from which the Balb/MK cell line was derived (53). We found that N-myc is not induced in cultured primary mouse keratinocytes that do not normally express $\mathrm{N}-m y c$ in vivo (data not shown). Taken together, these observations indicate that $\mathrm{N}-m y c$ expression in Balb/MK cells is not associated with a transforming event, and suggest that the Balb/MK cell line originated from a progenitor cell from the outer root sheath of the hair bulb that normally expresses $\mathrm{N}-m y$ c in vivo $(51,52)$. Thus, Balb/MK is a previ- ously well-characterized, nontransformed cell line that we have shown to be useful to study mechanisms that regulate N-myc expression. As such, the Balb/MK cell line may reveal important information about the regulation of $\mathrm{N}-m y c$ during development, as well as the mechanisms that might regulate the proliferation of cells involved in hair growth.

TGF- $\boldsymbol{\beta} 1$ inhibits myc. We found that TGF- $\beta 1$ inhibited $\mathrm{N}-m y c$ expression in Balb/MK cells, and the inhibition occurred well in advance of detectable changes in cell cycle distribution. The functions of $\mathrm{N}-m y c$ as a regulator of cell growth suggest that the inhibition of $\mathrm{N}-m y c$ is an important mediator of the TGF- $\beta 1$ growth inhibition signal. N-myc has growth-promoting activities similar to c-myc and L-myc in vivo and in vitro, and $\mathrm{N}-m y c$ overexpression has been implicated in a variety of malignancies [reviewed in Marcu et al. (43)]. Although the activity of N-myc in regulating cell growth is thought to be similar to c-myc, the normal expression patterns of these genes during development differs markedly, and each has essential functions that are not compensated for by other $m y c$ proteins $(51,54-56)$. Our observation that $\mathrm{N}-m y c$ and c-myc have different patterns of expression during the $\mathrm{G}_{1}$ phase of the cell cycle in Balb/MK cells suggests that $\mathrm{N}-m y c$ and c-myc are subject to dissimilar regulatory forces, and their proteins serve highly individualized, nonoverlapping functions in Balb/MK cells. c-myc appears to be necessary for cell proliferation, and the inhibition of c-myc expression in $\mathrm{Balb} / \mathrm{MK}$ cells is sufficient to inhibit cell growth (57). Similarly, $\mathrm{N}-m y c$ is essential for the proliferation of cells in which it is expressed. Antisense N-myc expression in neuroblastoma cell lines inhibited soft agar growth, indicating that $\mathrm{N}-m y c$ plays an essential role in the proliferation of these cancer cells (58-60). Furthermore, homozygous disruption in the N-myc gene in mice resulted in embryonic lethality with multiple defects thought to be caused by impaired cell proliferation in epithelial tissues that normally express N-myc (56, 61-63). Recently, activation of a conditional c-Myc-estrogen receptor chimera in Balb/MK cells resulted in resistance to TGF- $\beta 1$ induced late $G_{1}$ arrest, indicating that c-Myc overactivity is sufficient to override the inhibitory effects of TGF- $\beta 1$ on cell cycle progression (34). Taken together, these data support the conclusion that inhibition of c-myc, and probably also N-myc, is necessary for TGF- $\beta 1$-mediated growth inhibition of Balb/MK cells. The fact that N-myc has similar growthpromoting properties to c-myc suggests that deregulated N-myc expression is a mechanism that allows cancer cells to escape TGF- $\beta 1$-induced growth arrest.

Evidence that TGF- $\beta 1$ may regulate essential functions of $\mathrm{N}-m y c$ during development comes from studies of normal epithelial development in mice. Using a gene knockout approach, mice expressing subnormal levels of N-myc were generated by the fortuitous insertion of a neomycin cassette into the first intron of the N-myc gene (64). The cassette, intended to disrupt the gene, was occasionally spliced from the mRNA resulting in low levels of a normal N-myc transcript. Mice homozygous for this mutation died of respiratory distress shortly after birth and were found to have a marked inhibition in pulmonary airway branching (64). Subsequently it was shown that the TGF- $\beta 1$-mediated inhibition of airway branch- 
ing morphogenesis of 11.5- to 14.5-d murine lung explant cultures was associated with an inhibition of N-myc mRNA expression in the distal airway epithelium (65). Inasmuch as TGF- $\beta 1$ expression is normally found in the airway epithelium (66), these data suggest that TGF- $\beta 1$ plays an important role in the modulation of $\mathrm{N}-m y c$ expression in the lung. On the basis of colocalization, TGF- $\beta 1$ might regulate $\mathrm{N}-m y c$ expression in the hair bulb $(52,67)$, just as it might regulate $\mathrm{N}-m y c$ expression in multiple developing epithelial tissues where both are expressed. The inhibition of $\mathrm{N}-m y c$ by TGF- $\beta 1$ appears to require the presence of $\mathrm{pRb}$, as $\mathrm{N}-m y c$ inhibition was not seen in TGF- $\beta 1$-treated lung bud explants from Rb-gene knockout mice (68). Beyond this, the mechanism of TGF- $\beta 1$ inhibition of $\mathrm{N}-m y c$ expression in normal cells has remained largely unknown.

Our data suggest that TGF- $\beta 1$ inhibits N-myc mRNA synthesis in Balb/MK cells, because TGF- $\beta 1$ treatment did not affect mRNA stability. Because TGF- $\beta 1$ has been shown to inhibit transcription of the c-myc promoter through a sequence called the TGF- $\beta 1$ control element (TCE), we have examined the N-myc promoter for regions similar to the consensus TCE (42). The sequence for the consensus TCE (GNGTNGGNGA) was proposed on the basis of comparison of the c-myc TCE with the TGF- $\beta 1$ inhibitory element (TIE) in the transin/ stromelysin gene (42). The mouse N-myc promoter contains several regions of homology to the consensus TCE. Regions differing by only one base from the consensus are found at $-1021,-224,-162,-137$, and -74 . The region from -169 to -112 contains seven tandem or overlapping repeats that differ by only one or two bases from the consensus TCE. The identification of regions in the $\mathrm{N}-m y c$ promoter that are similar to the consensus TCE suggests that the inhibition of N-myc and c-myc may be mediated through the same mechanism.

TGF- $\beta 1$ induces Mxi1 and Mad4. Our results provide the first evidence that TGF- $\beta 1$ induces the expression of genes, Mxil and Mad4, that directly antagonize myc function. By antagonizing Myc activity, Mxil and Mad4 appear to function as tumor suppressors $(69,70)$. One function of TGF- $\beta 1$ that is critical for preserving tissue homeostasis is the ability of TGF- $\beta 1$ to suppress tumor formation $(34,71)$. The tumor suppressor functions of TGF- $\beta 1$ appear to be predominantly related to the growth arrest signal, whereby TGF- $\beta 1$ inhibits proto-oncogenes and activates tumor suppressor genes. The ability of TGF- $\beta 1$ to inhibit cell growth is commonly lost as normal cells transform into cancer, and many of the alterations in gene expression that lead to cancer also appear to allow cells to escape TGF- $\beta 1$-induced growth arrest. Thus, one of the hallmark features of TGF- $\beta 1$ is its ability to activate the functions of tumor suppressor genes, and our observation that TGF- $\beta 1$ induces the expression of Mxil and Mad4 is consistent with this paradigm.

Interestingly, Mxil and Mad4 are thought to have essential roles in the process of cell differentiation during development (70), yet the $\mathrm{G}_{1}$ arrest of both Balb/MK and Mv1Lu cells in response to TGF- $\beta 1$ is completely reversible, and permanent phenotypic changes have not been described. Our results suggest that the role of Mxil and Mad4 induction by TGF- $\beta 1$ may be limited to inhibiting cell growth, rather than initiating cell differentiation. In this regard, our findings are similar to the reports indicating that Myc antagonists appear to mediate cell cycle arrest in the absence of differentiation in response to interferon (72) and serum withdrawal (73). Because induction of a myc antagonist such as Mxil or Mad4 has been shown uniformly to be sufficient to arrest cell growth $(36,69,74,75)$, it appears that induction of Mxil or Mad4 by TGF- $\beta 1$ might be sufficient to mediate cell cycle arrest in the rare circumstance in which c-myc does not appear to be inhibited by TGF- $\beta 1$. In other words, the induction of Mxil and Mad4 expression by TGF- $\beta 1$ alters the threshold so that the cell subsequently requires higher levels of $m y c$ expression to sustain cell growth.

In summary, the novel finding that TGF- $\beta 1$ regulates the expression of N-myc, Mxil, and Mad4 in Balb/MK cells supports the idea that these transcription factors mediate essential functions of TGF- $\beta 1$. Until now, TGF- $\beta 1$ was thought to block myc function exclusively by inhibiting myc expression. However, when viewed as a larger regulatory scheme, the induction of Mxil and Mad4 mRNA expression by TGF- $\beta 1$ suggests that the ratios of these proteins shift to form a relative predominance of Mxi1-Max and Mad4-Max dimers. Earlier reports have firmly established that a predominance of Mxi1Max or Mad4-Max dimers will oppose the effect of Myc-Max dimers on the transcription of key growth regulatory genes, and thereby induce cell cycle arrest. Thus, our results suggest that the induction of Mad4 and Mxil may function in tandem with the inhibition of $\mathrm{N}-m y c$ and c-myc to mediate the growth inhibitory and tumor suppressor functions of TGF- $\beta 1$. Although we have demonstrated that TGF- $\beta 1$ regulates the expression of multiple Max-interacting factors in two cell lines commonly used as model systems for studying TGF- $\beta 1$ induced growth arrest, it remains to be determined whether TGF- $\beta 1$ might target Max-interacting transcription factors in a cell type-specific manner. For example, it is possible that TGF- $\beta 1$ might affect the expression of Max-interacting factors other than N-myc, c-myc, Mxil, and Mad4 in certain cell types. Further studies are needed to determine the degree to which the induction of Mxil and Mad4 may mediate the effects of TGF- $\beta 1$ signaling on cell growth or differentiation during development. In addition, the relative importance of the distinct mRNA expression patterns of these genes in Balb/MK cells awaits a more comprehensive understanding of the relative abundance and transcriptional targets of the Maxcontaining protein dimers during the cell cycle.

Acknowledgments. The authors thank Don Ayer, Kristi Neufeld, Kurt Albertine, and Bill Carroll for their critical review and helpful comments on the manuscript. We thank each of the investigators who contributed reagents (see Methods). We are grateful to Pauline Cordray and Agnieszka Gorska for expert technical assistance and to Wayne Green for assistance with FACS analysis.

\section{REFERENCES}

1. Wall NA, Hogan BL 1994 TGF-beta related genes in development. Curr Opin Genet Dev 4:517-522

2. Massague J, Chen YG 2000 Controlling TGF-beta signaling. Genes Dev 14:627-644 
3. Raff MC 1996 Size control: the regulation of cell numbers in animal development. Cell 86:173-175

4. Moses HL, Yang EY, Pietenpol JA 1990 TGF- $\beta$ stimulation and inhibition of cell proliferation: new mechanistic insights. Cell 63:245-247

5. Sporn MB, Roberts AB 1992 Transforming growth factor-beta: recent progress and new challenges. J Cell Biol 119:1017-1021

6. Pardee AB $1989 \mathrm{G}_{1}$ events and regulation of cell proliferation. Science 246:603-608

7. Pietenpol JA, Stein RW, Moran E, Yaciuk P, Schlegel R, Lyons RM, Pittelkow MR, Munger K, Howley PM, Moses HL 1990 TGF- $\beta 1$ inhibition of c-myc transcription and growth in keratinocytes is abrogated by viral transforming proteins with $\mathrm{pRB}$ binding domains. Cell 61:777-785

8. Laiho M, DeCaprio JA, Ludlow JW, Livingston DM, Massague J 1990 Growth inhibition by TGF-beta linked to suppression of retinoblastoma protein phosphorylation. Cell 62:175-185

9. Howe PH, Draetta G, Leof EB 1991 Transforming growth factor beta 1 inhibition of p34cdc2 phosphorylation and histone H1 kinase activity is associated with $G_{1} / S$ phase growth arrest. Mol Cell Biol 11:1185-1194

10. Satterwhite DJ, Aakre ME, Gorska AE, Moses HL 1994 Inhibition of cell growth by TGF beta 1 is associated with inhibition of B-myb and cyclin A in both BALB/MK and Mv1Lu cells. Cell Growth Differ 5:789-799

11. Nevins JR 1992 E2F: a link between the Rb tumor suppressor protein and viral oncoproteins. Science 258:424-429

12. Münger K, Pietenpol JA, Pittelkow MR, Holt JT, Moses HL 1992 Transforming growth factor $\beta 1$ regulation of c-myc expression, $\mathrm{pRB}$ phosphorylation, and cell cycle progression in keratinocytes. Cell Growth Differ 3:291-298

13. Ko TC, Sheng HM, Reisman D, Thompson EA, Beauchamp RD 1995 Transforming growth factor- $\beta 1$ inhibits cyclin D1 expression in intestinal epithelial cells. Oncogene 10:177-184

14. Hannon GJ, Beach D $1994 \mathrm{p} 15^{\mathrm{INK} 4 \mathrm{~B}}$ is a potential effector of TGF- $\beta$-induced cell cycle arrest. Nature 371:257-261

15. Reynisdóttir I, Polyak K, Iavarone A, Massagué J 1995 Kip/Cip and Ink4 Cdk inhibitors cooperate to induce cell cycle arrest in response to TGF- $\beta$. Genes Dey 9:1831-1845

16. Steiner P, Philipp A, Lukas J, Godden-Kent D, Pagano M, Mittnacht S, Bartek J, Eilers M 1995 Identification of a Myc-dependent step during the formation of active $\mathrm{G}_{1}$ cyclin-cdk complexes. EMBO J 14:4814-4826

17. Daksis JI, Lu RY, Facchini LM, Marhin WW, Penn LJZ 1994 Myc induces cyclin D1 expression in the absence of de novo protein synthesis and links mitogen-stimulated signal transduction to the cell cycle. Oncogene 9:3635-3645

18. Hoang AT, Cohen KJ, Barrett JF, Bergstrom DA, Dang CV 1994 Participation of cyclin A in Myc-induced apoptosis. Proc Natl Acad Sci USA 91:6875-6879

19. Jansen-Dürr P, Meichle A, Steiner P, Pagano M, Finke K, Botz J, Wessbecher J, Draetta G, Eilers M 1993 Differential modulation of cyclin gene expression by $M Y C$. Proc Natl Acad Sci USA 90:3685-3689

20. Goodrich DW, Lee W-H 1992 Abrogation by c-myc of $\mathrm{G}_{1}$ phase arrest induced by RB protein but not by $\mathrm{p} 53$. Nature $360: 177-179$

21. Grandori C, Eisenman RN 1997 Myc target genes. Trends Biochem Sci 22:177-181

22. Obaya AJ, Mateyak MK, Sedivy JM 1999 Mysterious liaisons: the relationship between c-Myc and the cell cycle. Oncogene 18:2934-2941

23. Heikkila R, Schwab G, Wickstrom E, Loke SL, Pluznik DH, Watt R, Neckers LM 1987 A c-myc antisense oligodeoxynucleotide inhibits entry into $\mathrm{S}$ phase but not progress from $G_{0}$ to $G_{1}$. Nature 328:445-449

24. Prochownik EV, Kukowska J, Rodgers C 1988 c-myc antisense transcripts accelerate differentiation and inhibit $\mathrm{G}_{1}$ progression in murine erythroleukemia cells. Mol Cell Biol 8:3683-3695

25. Mateyak MK, Obaya AJ, Adachi S, Sedivy JM 1997 Phenotypes of c-Myc-deficient rat fibroblasts isolated by targeted homologous recombination. Cell Growth Differ 8:1039-1048

26. Coffey Jr RJ, Bascom CC, Sipes NJ, Graves-Deal R, Weissman BE, Moses HL 1988 Selective inhibition of growth-related gene expression in murine keratinocytes by transforming growth factor beta. Mol Cell Biol 8:3088-3093

27. Takehara K, LeRoy EC, Grotendorst GR 1987 TGF-beta inhibition of endothelial cell proliferation: alteration of EGF binding and EGF-induced growth-regulatory (competence) gene expression. Cell 49:415-422

28. Fernandez-Pol JA, Talkad VD, Klos DJ, Hamilton PD 1987 Suppression of the EGF-dependent induction of c-myc proto-oncogene expression by transforming growth factor-beta in a human breast carcinoma cell line. Biochem Biophys Res Commun 144:1197-1205

29. Mulder KM, Humphrey LE, Choi HG, Childress-Fields KE, Brattain MG 1990 Evidence for c-myc in the signaling pathway for TGF-beta in well-differentiated human colon carcinoma cells. J Cell Physiol 145:501-507

30. Ruegemer JJ, Ho SN, Augustine JA, Schlager JW, Bell MP, McKean DJ, Abraham RT 1990 Regulatory effects of transforming growth factor-beta on IL-2- and IL-4 dependent T cell-cycle progression. J Immunol 144:1767-1776

31. Landesman Y, Pagano M, Draetta G, Rotter V, Fusenig NE, Kimchi A 1992 Modifications of cell cycle controlling nuclear proteins by transforming growth factor $\beta$ in the HaCaT keratinocyte cell line. Oncogene 7:1661-1665

32. Zentella A, Weis FMB, Ralph DA, Laiho M, Massague J 1991 Early gene responses to transforming growth factor- $\beta$ in cells lacking growth-suppressive RB function. Mol Cell Biol 11:4952-4958

33. Warner BJ, Blain SW, Seoane J, Massague J 1999 Myc downregulation by transforming growth factor beta required for activation of the p15(Ink4b) G(1) arrest pathway. Mol Cell Biol 19:5913-5922

34. Alexandrow MG, Kawabata M, Aakre M, Moses HL 1995 Overexpression of the c-Myc oncoprotein blocks the growth-inhibitory response but is required for the mitogenic effects of transforming growth factor $\beta 1$. Proc Natl Acad Sci USA 92:3239-3243

35. Ayer DE, Kretzner L, Eisenman RN 1993 Mad: a heterodimeric partner for Max that antagonizes Myc transcriptional activity. Cell 72:211-222

36. Hurlin PJ, Queva C, Koskinen PJ, Steingrimsson E, Ayer DE, Copeland NG, Jenkin NA, Eisenman RN 1995 Mad3 and Mad4: novel Max-interacting transcriptional repressors that suppress c-myc dependent transformation and are expressed during neural and epidermal differentiation. EMBO J 14:5646-5659

37. Zervos AS, Gyuris J, Brent R 1993 Mxi1, a protein that specifically interacts with Max to bind Myc-Max recognition sites. Cell 72:223-232

38. Pazin MJ, Kadonaga JT 1997 What's up and down with histone deacetylation and transcription? Cell 89:325-328

39. Solomon DL, Amati B, Land H 1993 Distinct DNA binding preferences for the c-Myc/Max and Max/Max dimers. Nucleic Acids Res 21:5372-5376

40. Fisher F, Crouch DH, Jayaraman PS, Clark W, Gillespie DAF, Goding CR 1993 Transcription activation by Myc and Max: flanking sequences target activation to a subset of CACGTG motifs in vivo. EMBO J 12:5075-5082

41. Cole MD, McMahon SB 1999 The Myc oncoprotein: a critical evaluation of transactivation and target gene regulation. Oncogene 18:2916-2924

42. Pietenpol JA, Munger K, Howley PM, Stein RW, Moses HL 1991 Factor-binding element in the human c-myc promoter involved in transcriptional regulation by transforming growth factor $\beta 1$ and by the retinoblastoma gene product. Proc Nat Acad Sci USA 88:10227-10231

43. Marcu KB, Bossone SA, Patel AJ 1992 myc function and regulation. Annu Rev Biochem 61:809-860

44. Drozdoff V, Pledger WI 1993 Commitment to differentiation and expression of early differentiation markers in murine keratinocytes in vitro are regulated independently of extracellular calcium concentrations. J Cell Biol 123:909-919

45. Tlsty T, Briot A, Poulose B 1995 Analysis of cell cycle checkpoint status in mammalian cells. Methods Enzymol 254:125-133

46. Chomczynski P, Sacchi N 1987 Single-step method of RNA isolation by acid guanidium thiocyanate-phenol-chloroform extraction. Anal Biochem 162:156-159

47. Johnson MD, Gold LI, Moses HL 1992 Evidence for transforming growth factor-beta expression in human leptomeningeal cells and transforming growth factor-beta-like activity in human cerebrospinal fluid. Lab Invest 67:360-368

48. Blackwood EM, Eisenman RN 1991 Max: a helix-loop-helix zipper protein that forms a sequence-specific DNA-binding complex with Myc. Science 251:1211-1217

49. Resar LMS, Dolde C, Barrett JF, Dang CV 1993 B-myc inhibits neoplastic transformation and transcriptional activation by c-myc. Mol Cell Biol 13:1130-1136

50. Sehgal PB, Dannel JE, Tamm I 1994 The inhibition by DRB (5,6 dichloro-1-betaD-ribofuranosylbenzimidazole) of hnRNA and mRNA production in HeLa cells. Cell 9:473-480

51. Mugrauer G, Alt FW, Ekblom P 1988 N-myc proto-oncogene expression during organogenesis in the developing mouse as revealed by in situ hybridization. J Cell Biol 107:1325-1335

52. Sutton R, Cam GR, Ward WG, Raphael KA, Ward KA 1991 Myc protooncogenes of wool and hair growth. Ann NY Acad Sci 642:326-338

53. Weissman BE, Aaronson SA 1983 BALB and Kirsten murine sarcoma viruses alter growth and differentiation of EGF-dependent BALB/c mouse epidermal keratinocyte lines. Cell 32:599-606

54. Zimmerman KA, Yancopoulos GD, Collum RG, Smith RK, Kohl NE, Denis KA, Nau MM, Witte ON, Toran-Allerand D, Gee CE, Minna JD, Alt FW 1986 Differential expression of myc family genes during murine development. Nature 319:780-783

55. Hirning U, Schmid P, Schulz WA, Rettenberger G, Hameister H 1991 A comparative analysis of N-myc and c-myc expression and cellular proliferation in mouse organogenesis. Mech Dev 33:119-125

56. Stanton BR, Parada LF 1992 The N-myc proto-oncogene: developmental expression and In Vivo site-directed mutagenesis. Brain Pathol 2:71-83

57. Pietenpol JA, Holt JT, Stein RW, Moses HL 1990 Transforming growth factor $\beta-1$ suppression of c-myc gene transcription: role in inhibition of keratinocyte proliferation. Proc Natl Acad Sci USA 87:3758-3762

58. Rosolen A, Whitesell L, Ikegaki N, Kennett RH, Neckers LM 1990 Antisense inhibition of single copy N-myc expression results in decreased cell growth without reduction of c-myc protein in a neuroepithelioma cell line. Cancer Res 50:6316-6322

59. Larcher JC, Basseville M, Vayssiere JL, Cordeau-Lossouarn L, Croizat B, Gros F 1992 Growth inhibition of N1E-115 mouse neuroblastoma cells by c-myc or N-myc antisense oligodeoxynucleotides causes limited differentiation but is not coupled to neurite formation. Biochem Biophys Res Commun 185:915-924

60. Schmidt ML, Salwen HR, Manohar CF, Ikegaki N, Cohn SL 1994 The biological effects of antisense N-myc expression in human neuroblastoma. Cell Growth Differ 5:171-178

61. Charron J, Malynn BA, Fisher P, Stewart V, Jeannotte L, Goff SP, Robertson EJ, Alt FW 1992 Embryonic lethality in mice homozygous for a targeted disruption of the N-myc gene. Genes Dev 6:2248-2257

62. Stanton BR, Perkins AS, Tessarollo L, Sassoon DA, Parada LF 1992 Loss of N-myc function results in embryonic lethality and failure of the epithelial component of the embryo to develop. Genes Dev 6:2235-2247

63. Sawai S, Shimono A, Wakamatsu Y, Palmes C, Hanaoka K, Kondoh H 1993 Defects of embryonic organogenesis resulting from targeted disruption of the N-myc gene in the mouse. Development 117:1445-1455

64. Moens CB, Auerbach AB, Conlon RA, Joyner AL, Rossant J 1992 A targeted mutation reveals a role for $\mathrm{N}$-myc in branching morphogenesis in the embryonic mouse lung. Genes Dev 6:691-704 
65. Serra R, Pelton RW, Moses HL 1994 TGF $\beta 1$ inhibits branching morphogenesis and N-myc expression in lung bud organ cultures. Development 120:2153-2161

66. Heine UI, Munoz EF, Flanders KC, Roberts AB, Sporn MB 1990 Colocalization of TGF-beta1 and collagen I and III, fibronectin and glycosaminoglycans during lung branching morphogenesis. Development 109:29-36

67. Foitzik K, Lindner G, Mueller-Roever S, Maurer M, Botchkareva N, Botchkarev V, Handjiski B, Metz M, Hibino T, Soma T, Dotto GP, Paus R 2000 Control of murine hair follicle regression (catagen) by TGF-beta1 in vivo. FASEB J 14:752760

68. Serra R, Moses HL $1995 \mathrm{pRb}$ is necessary for inhibition of N-myc expression by TGF- $\beta 1$ in embryonic lung organ cultures. Development 121:3057-3066

69. Schreiber-Agus N, Meng Y, Hoang T, Hou Jr H, Chen K, Greenberg R, CordonCardo C, Lee HW, DePinho RA 1998 Role of Mxi1 in ageing organ systems and the regulation of normal and neoplastic growth. Nature 393:483-487

70. Queva C, Hurlin PJ, Foley KP, Eisenman RN 1998 Sequential expression of the MAD family of transcriptional repressors during differentiation and development. Oncogene 16:967-977

71. Pierce Jr DF, Gorska AE, Chytil A, Meise KS, Page DL, Coffey Jr RJ, Moses HL 1995 Mammary tumor suppression by transforming growth factor $\beta 1$ transgene expression. Proc Natl Acad Sci USA 92:4254-4258

72. Dey A, Kim L, Li W 1999 Gamma interferon induces expression of Mad1 gene in macrophage, which inhibits colony-stimulating factor-1-dependent mitogenesis. J Cell Biochem 72:232-241

73. Shimizu E, Shirasawa H, Kodama K, Sato T, Simizu B 1996 Expression, regulation and polymorphism of the mxi1 genes. Gene 176:45-48

74. Roussel MF, Ashmun RA, Sherr CJ, Eisenman RN, Ayer DE 1996 Inhibition of cell proliferation by the Mad1 transcriptional repressor. Mol Cell Biol 16:2796-2801

75. Chen J, Willingham T, Margraf LR, Schreiber-Agus N, DePinho RA, Nisen PD 1995 Effects of the MYC oncogene antagonist, MAD, on proliferation, cell cycling and the malignant phenotype of human brain tumour cells. Nat Med 1:638-643 